\title{
Zirconium Zr 89 Trastuzumab
}

National Cancer Institute

\section{Source}

National Cancer Institute. Zirconium Zr 89 Trastuzumab. NCI Thesaurus. Code $C 90575$.

A radioimmunoconjug ate containing the recombinant humanized monoclonal antibody trastuzumab labeled with the radioisotope zirconium $\mathrm{Zr} 89$ with radioisotopic activity and potential use as an imaging agent. The trastuzumab moiety of zirconium $\mathrm{Zr} 89$ trastuzumab binds with high affinity to the extracellular domain of human epidermal growth factor receptor 2 (HER2). Upon binding, the radioisotope moiety may be detected using positron emission tomography (PET), thereby allowing the imag ing and quantification of HER2-expressing tumor cells. HER2, a tyrosine kinase client protein of heat shock protein 90 (Hsp90), may be overexpressed on the cell surfaces of various tumor cell types. 